J. Perinat. Med. 15 (1987) 271

\section{Color flow mapping in obstetrics}

\author{
Asim Kurjak, Branko Breyer, Davor Jurković, Žarko Alfirević, and Mladen \\ Miljan
}

Ultrasonic Institute, University of Zagreb, Yugoslavia

\section{Introduction}

Blood flow velocity can conventionally be measured by the continuous wave and pulsed Doppler techniques. Flow can be quantitatively measured with the least velocity limitations by using continuous wave Doppler. Being continuous, the ultrasound wave has no depth resolution. This means that any flow which happens to run somewhere along the beam will contribute to the final measurement. In cases when one can be sure that only one blood vessel is hit by the ultrasound beam the result will be satisfactory.

The advantages of these systems are twofold: there are no high velocity limitations and the cost of such instruments is lower than that of other types.

The position of the deep-lying vessels in the moving fetus as related to the ultrasound beam is unknown, and it is difficult to keep them in the path of the beam. By using pulsed wave Doppler, which is depth selective, blood flow in particular fetal vessels, e. g., the fetal aorta or umbilical vein, can be analyzed. Depth selection is achieved by imposing a time delay in the reception of echoes from the transmitted pulse. The position and the volume of the sample along the beam axis determinate the delay as well as reception time. The position of the sample is controlled on the B-scan which can be used alternately with the Doppler system. The limitation in this case is posed by the upper limit for high velocity measurement. If the sampling theorem is violated, velocity measurement results will include artefacts which cannot be eliminated by any available mathematical method [9]. The limitation depends on the number of samples per second in pulsed Doppler measurements and, therefore, is less restrictive in shallow blood flow measurements than in cases when the flow is located deep in the body.

Continuous and pulsed Doppler measurements provide fairly elaborate results. Raw Doppler shifts can be analyzed in different ways, and spectral velocity, volume, pulsatility and turbulence data can be obtained. All these data are obtained from very restricted areas within the body so that probe aiming becomes critical, while obtaining data from an area requires long and tedious effort.

Pulsed Doppler is now used extensively in fetal circulation studies. Abnormalities in fetal peripheral circulation can be used as an important diagnostic parameter for the assessment of fetal well-being, especially in cases of placental insufficiency and consecutive intrauterine growth retardation $[2,3,5,8]$.

Sometimes a semiquantitative overview of flow velocities and directions within an area, rather than strict quantitative flow analysis, will provide clinical information most rapidly. This can be achieved by flow mapping. Like many others, the basic principle has first been devel- 
oped for military use in moving target identification radar. The comparison of consecutive images, based on the subtraction of images obtained from the same area at different times is the simplest method for identifying moving reflectors. When two subsequent two-dimensional images are subtracted, the non-moving reflectors vanish and only the subsequent positions of moving reflectors appear in the image. This, the simplest approach suffers from major limitations at higher velocities; the multiplication of subsequent images yields measurements with fewer restrictions.

By applying the moving target identification principle to an ultrasonic diagnostic instrument using sound waves instead of radio waves, blood flow in the heart or large vessels can be displayed. Technically a delay line is used to bring data from subsequent images to a multiplier. This is, in fact, an autocorrelation calculation.

It can mathematically be shown that the autocorrelation function contains a number proportional to target movement velocity which can be automatically detected and displayed [4]. The limitations for color flow mapping are very similar to those affecting currently used pulsed Doppler instruments. As illustrated in table I, the sampling (pulse repetition rate) limits the velocities which can be color coded. The color code itself is additional quantitative limitation since it relies on subjective judgement of color and brightness. Furthermore, care must be exercised in interpreting flows running at $90^{\circ}$ to the scanning beam, because the flow will be

Table I. Maximum detectable velocity $(\mathrm{m} / \mathrm{s})$ related to probe frequency and pulse repetition frequency (PRF), $\cos \theta=1$; (From Aloka Color Doppler SSD-880 CW Operating Manual).

\begin{tabular}{l|llll}
\hline \multicolumn{1}{c|}{ PRF $(\mathrm{KHz})$} & 4 & 6 & 8 & 12 \\
$\begin{array}{l}\text { Freq. } \\
\text { of probe }(\mathrm{MHz})\end{array}$ & & & & \\
\hline 2.5 & 0.64 & 0.93 & 1.23 & 1.91 \\
3.5 & 0.48 & 0.70 & 0.93 & 1.43 \\
5.0 & 0.32 & 0.47 & 0.62 & 0.96 \\
\hline
\end{tabular}

shown at the opposite ends of an image in opposite colors while the indication vanishes at exactly $90^{\circ}$.

The aim of this study has been to evaluate the diagnostic potential of flow mapping in obstetrics, particularly in antenatal detection of congenital heart abnormalities and studies of blood flow in fetal peripheral vessels.

\section{Subjects and methods}

Color flow studies were performed by using an Aloka Color Doppler SSD-880 CW unit with 2.5 and $5 \mathrm{MHz}$ sector probes. In addition to the mapping function the machine is equipped with a conventional continuous and pulsed Doppler system which can be used simultaneously with B-mode imaging as in duplex Doppler systems. It should be emphasized that the machine under consideration was originally designed for studies of cardiac circulation in adults and children, and its obstetrics application was not specified by the manufacturer. The equipment was set for the display of unidirectional flow in basic red or blue color, and disturbed flow was expressed by a cyan or yellow variation in tint.

Twohundred and eleven pregnant women between 15 and 40 weeks of pregnancy were examined: 193 had uncomplicated pregnancies with a known gestational age, as confirmed by an early scan. The group with abnormal pregnancies included 11 cases of insulin dependant diabetes, 2 cases of $\mathrm{Rh}$-immunization, 2 cases of non-immune fetal hydrops of unknown cause associated with polyhydramnios, 2 cases of fetal cardiac structural defects and 1 case of intrauterine growth retardation.

Several parameters were studied, i. e., the possibility of clear intracardiac flow visualization, and the possibility of clear flow visualization in the aorta, umbilical artery and vein, and internal carotid artery.

The fetal heart was first visualized on the Bscan in four characteristic sections, i. e., the four chamber view, the parasternal long axis 


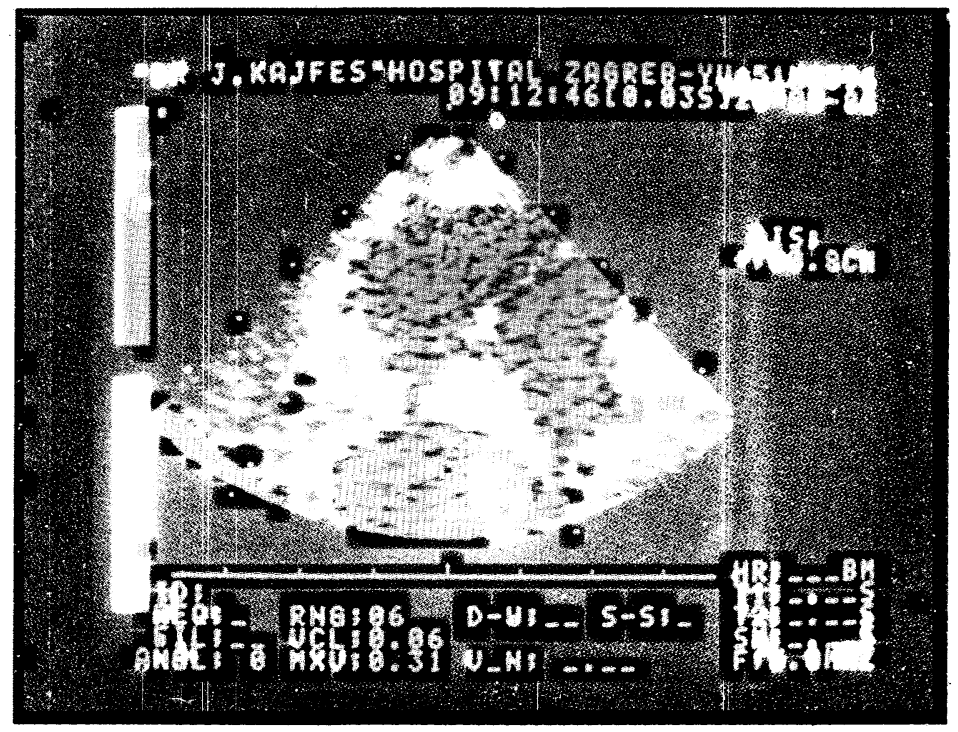

Figure 1. Flow mapping in the umbilical vein at 34th week of gestation illustrating opposite colors at the opposite ends of an image, while the flow indication vanishes at $90^{\circ}$. Unidirectional flow component (dark) and area of high velocity gradient alongside the vessel wall (light) are also visible.

view, the sagittal section demonstrating the aortic arch and the short axis through the base of the heart. After a good B-scan image was obtained, the color flow function was superimposed in the attempt to visualize flow through each particular part of the heart. The same approach was employed in studies of flow in large fetal vessels.

The study of blood flow in the umbilical vein was more detailed as compared with the other vessels. The loop of the cord was visualized close to the anterior uterine wall at standardized scan depth of $6 \mathrm{~cm}$ by using the $5 \mathrm{MHz}$ probe. The inner diameter of the vein was then measured by a built-in caliper system. At least three diameter measurements were performed and the mean value calculated. Flow was displayed next and flow width measured in the same way. When flow in the umbilical vein is displayed after 20 weeks of gestation two components denoted by variance in basic color can be distinguished. According to the manufacturer's specifications the dark flow component as illustrated in figure 1 corresponds to the area of approximately uniform velocity, while the light component alongside the vessel wall represents a mixture of the basic color (red or blue) with green and denotes a high velocity gradient. As these two components are separable in most cases after 20 weeks of pregnancy, we have tried to establish any changes in their area ratio during pregnancy and in certain pathological situations. The ratio of these two components was calculated by a video digitizer in a standardized segment of the vessel and then expressed as an index, $\frac{A_{1}-A_{2}}{A_{2}}$, where $A_{1}$ is the flow area in the $1 \mathrm{~cm}$ vessel segment and $A_{2}$ the area of the inner flow component. Statistical analysis was performed by using the Student's paired t-test.

\section{Results}

The best results in color flow mapping were obtained between the 20th and 24th weeks. At this gestational age intracardiac flow can easily be seen in $78 \%(35 / 45)$ of cases. The analysis was significantly improved when the fetus was 


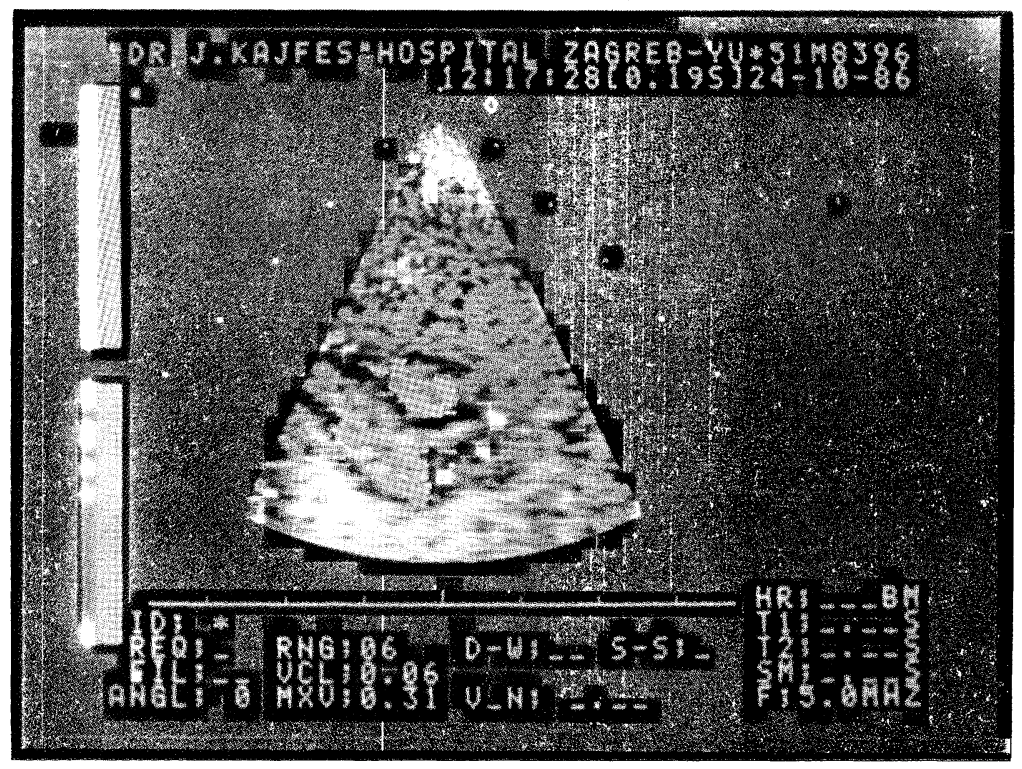

Figure 2. The four chamber view of the fetal heart at 24th week of gestation illustrating flow through the mitral and tricuspid valve (red).

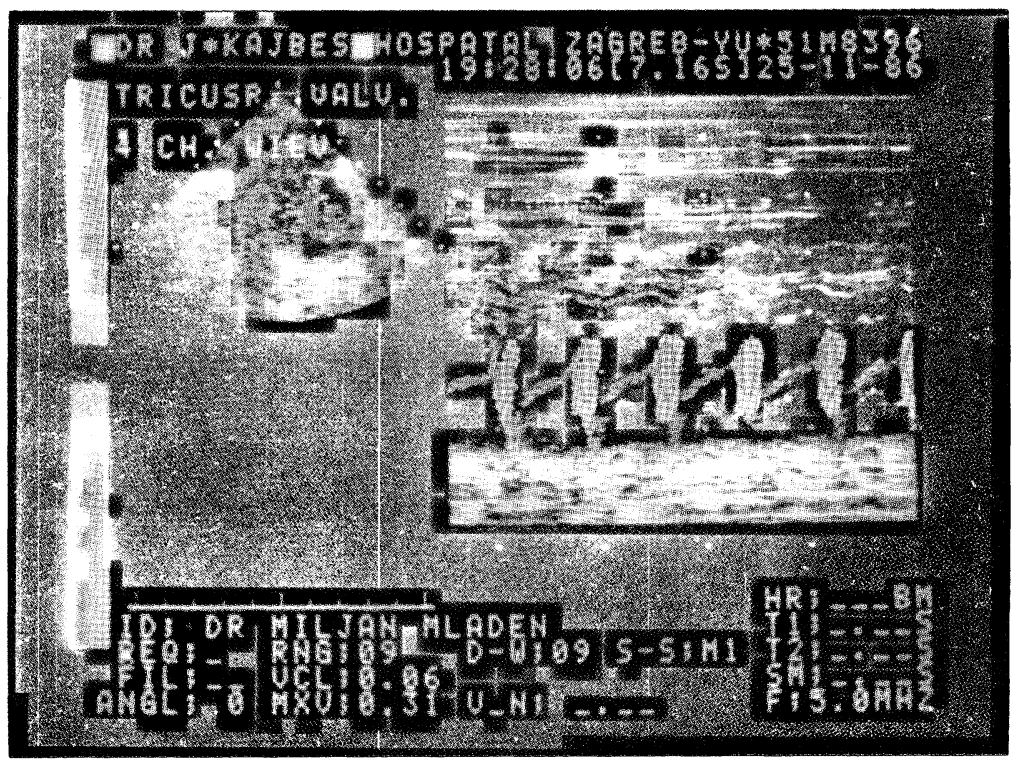

Figure 3. Flow through the tricuspid valve in normal heart as seen by flow mapping. On the left B-mode four chamber view with superimposed flow mapping is seen. On the right there is M-mode showing normal closure of the valve during ventricular systole. Diastolic flow through the valve is coded in red. The blue color which is seen in the middle of the flow indication is caused by aliasing effect due to high blood velocity.

lying on its back (figure 2). After the 24th week the heart flow visualization rate gradually decreases to $31 \%(11 / 36)$ before term. In two cases of fetal cardiac structural defects color flow mapping has been particularly useful for detailed assessment of abnormality. In both 


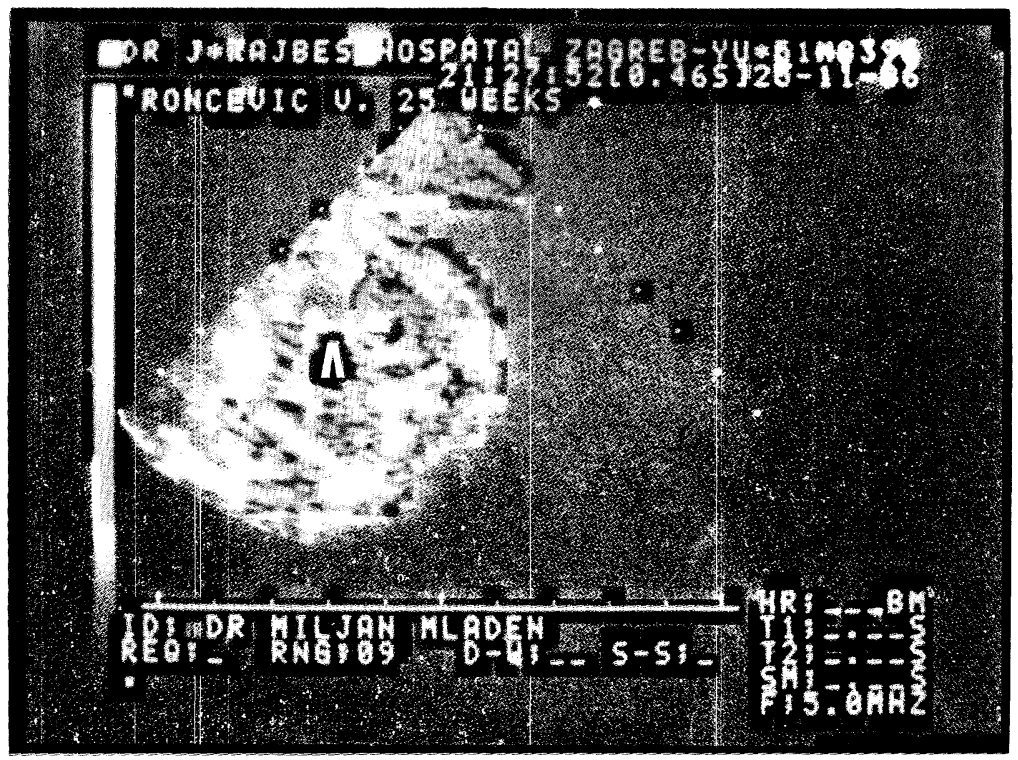

Figure 4. B-mode scan through the right atrium, right ventricle and left ventricle showing wide communication between the right atrium and ventricle due to tricuspid valve insufficiency (arrow).

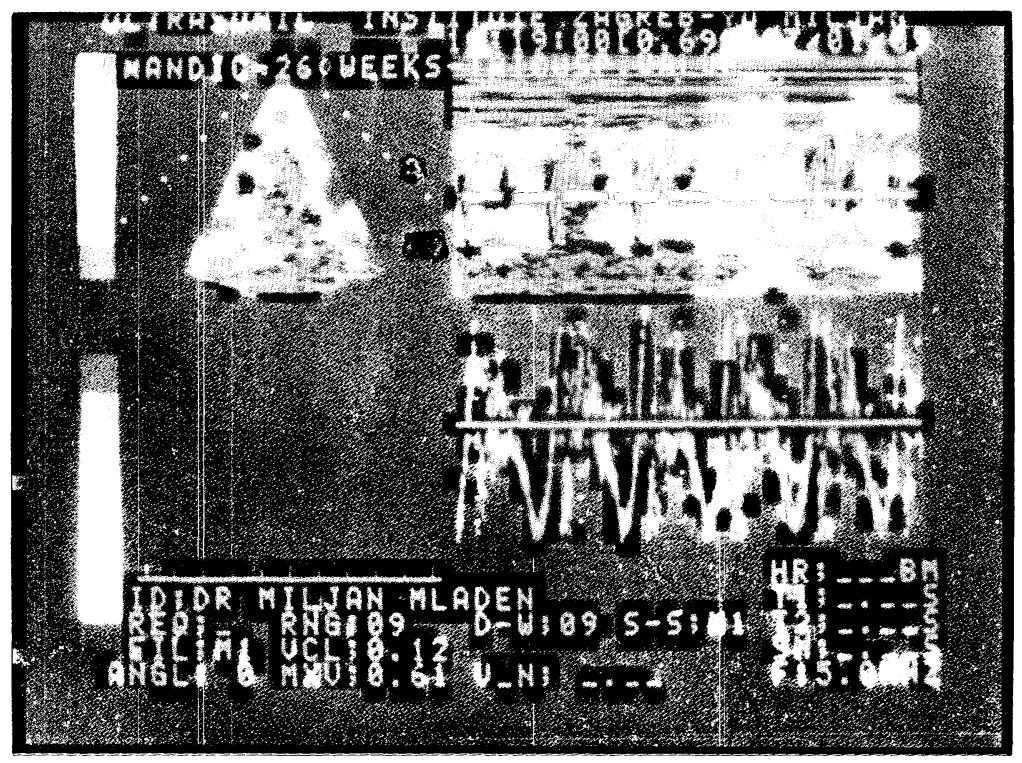

Figure 5. Flow mapping in the case of tricuspid valve insufficiency. On the upper right side of the figure the red color indicates the flow through the tricuspid valve in the ventricular diastole. The blue color indicates reverse flow through the valve during systole of the ventricle. Reverse flow was also recognized on pulsed Doppler as illustrated on lower right part.

cases diagnosis of the tricuspid valve insufficiency was easily made by demonstration of reverse flow through the valve during systole of the ventricles (figures $3,4,5$ ). Flow mapping was also helpful for the exclusion of a possible associated ventricular septal defect, but mild 
pulmonary stenosis, which was present in both cases at autopsy, could not be diagnosed with certainty. (A more detailed report of the role of color flow mapping in fetal cardiac structural defects assessment will be published later).

At the 24th week flow in the intrahepatic part of the umbilical vein can be seen in $42 \%$ (19/ $45)$ of cases. Poor results were obtained in studies of the fetal aorta which could be visualized in $11 \%(5 / 45)$ of cases while the internal carotid artery was not seen. All the other fetal vessels are deep-lying in the third trimester and are difficult to assess. The only exception are the vessels in the cord which are clearly seen even at 15 weeks.

In the period between 20 and 40 weeks these vessels were seen in $100 \%$ of cases. Generally, flow is displayed best when the angle between the blood stream in the vessel and the longitudinal transducer axis does not exceed $30^{\circ}$. The comparison between the diameter of the umbilical vein measured on the B-scan and flow width showed no significant difference $(\mathrm{t}=0.26$; $\mathrm{p}<0.01 ; \mathrm{N}=209$ ).

The two-component index or color flow index was calculated in 106 cases which included 101

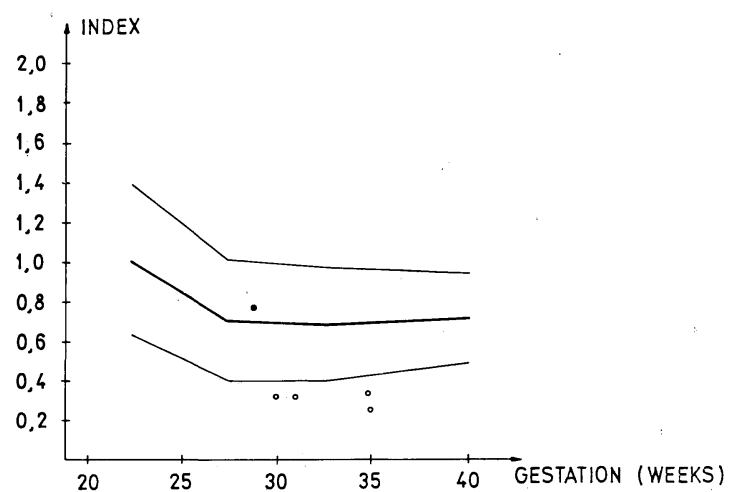

Figure 6. Graph illustrating the flow index changes from 20 th to 40 th week of gestation $(\bar{x} \pm 2 S D ; N=106)$.

$0-2$ cases of Rh-immunization and 2 cases of nonimmune fetal hydrops

- case of IUGR

normal cases, 2 cases of $\mathrm{Rh}$-immunization with bilirubin values in the amniotic fluid between the $\mathrm{B}$ and $\mathrm{C}$ groups, 2 cases of fetal hydrops and polyhydramnios, and 1 case of intrauterine growth retardation. The results are illustrated in figure 6.

As shown, in normal pregnancies the ratio is relatively high between the 20th and 26th weeks; the value then decreases and remains

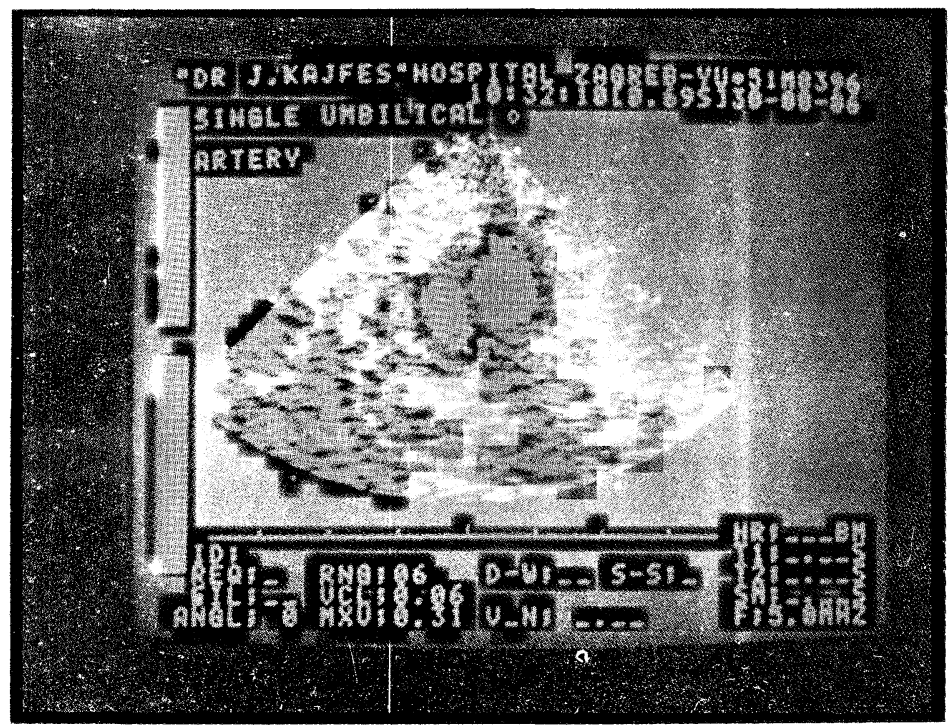

Figure 7. Case of single umbilical artery sindrome at 37 weeks. Note almost the same width of flow indication in the artery (red) and vein (blue). 
constant until term. In two cases of Rh-immunization and two cases of fetal hydrops which are marked separately, the index values were significantly lower than in the normal group. Marked dilatation of the umbilical vein was a common feature in all four cases. In one case of intrauterine growth retardation, which is also marked in figure 6 , the index was within normal limits.

By using flow mapping we could also diagnose a case of single umbilical artery syndrome in a diabetic patient at 37 weeks on the basis of extremely prominent flow in the umbilical artery which was almost as wide as flow in the vein (figure 7).

\section{Discussion}

The great value of color flow mapping has already been recognized in studies of intracardiac circulation in adults and children [6]. It provides for direct visualization of blood flow within the heart and relatively easy detection of any abnormal communication between cardiac cavities caused by congenital and aquired heart disease (figure 8). Examination of the fetal heart has recently become feasible in obstetric ultrasonography, and fetal echocardiography and blood flow studies are now generally accepted as methods for antenatal diagnosis of congenital heart disease and abnormalities of fetal peripheral circulation [3, 10].

Direct visualization of intracardiac flow by color flow. mapping can probably improve ultrasonic detection of various structural heart abnormalities. The two cases described illustrate that the method gives valuable information about valve function. It can also be useful for detection of small ventricular septal defects which are practically undetectable by conventional methods.

Flow mapping of fetal peripheral vessels has shown, in optimum conditions $(5 \mathrm{MHz}$ probe, low scanning depth and optimum angle), no significant difference between the vessel diameter measured on the B-scan and flow width. Accordingly, flow diameter can be used for vessel diameter estimation in situations when the investigated vessel lies parallel to the ultrasound beam. In such cases B-mode scanning

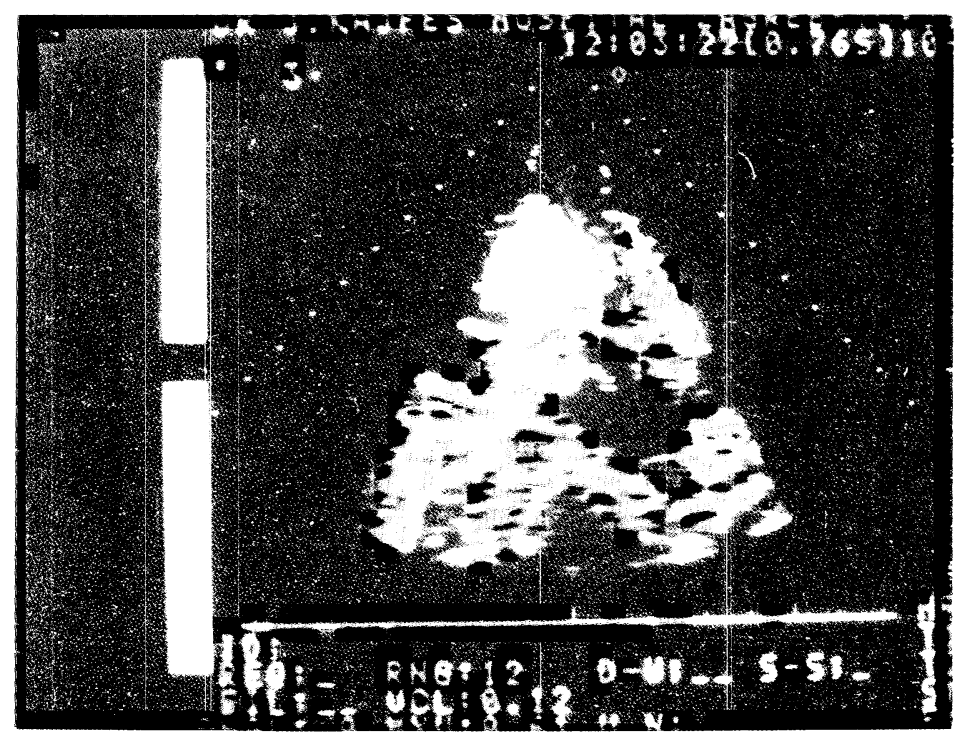

Figure 8. Flow mapping of the heart in a 2 months old baby showing the mitral valve, the left ventricle outflow tract flow (blue) and flow through ventricular septal defect above (red). 
measurements of the diameter are not reliable because of poor axial resolution.

Moreover, flow mapping provides not only for the visualization of flow direction but also yields some information on flow profile. All Doppler analyses in clinical practice are now based on the evaluation of peak velocity changes during a cycle, but provide only limited information on flow profile. As illustrated in figure 6, flow profile in the fetal umbilical vein changes during pregnancy. Significant flow profile changes were also observed in 2 cases of $\mathrm{Rh}$-immunization and 2 cases of fetal hydrops. This finding can be explained both by vessel dilatation and lower blood viscosity due to fetal anemia in these cases. One case of single umbilical artery syndrome was also diagnosed by flow mapping. As this condition is frequently associated with prematurity, early neonatal death, and gross fetal malformations, meticulous evaluation of fetal anatomy and appropriate obstetrical management is required [7]. In all five cases with abnormal flow profile examinations were also performed by conventional

\section{Summary}

Blood flow studies are now used extensively in evaluating fetal peripheral circulation. By using continuous and pulsed Doppler ultrasonic equipment the raw Doppler shifts caused by blood moving in the vessels can be analyzed in different ways. Spectral data can be used to estimate blood velocity and volume in the vessel, and pulsatility characteristics and turbulence. All these data are obtained from very restricted areas within the body so that aiming of the probe is critical, and obtaining data from an area requires long and tedious effort. Color flow mapping which has recently been introduced into clinical practice provides an overview of flow velocities and directions within an area. Color coded flow can be displayed by applying the moving target identification principle (as in radar) to an ultrasonic diagnostic instrument where sound waves are used instead of radio waves. The value of flow mapping has already been recognized in the diagnosis of congenital and aquired heart disease in adults and children. Direct visualization of intracardiac flow provides for a fast and accurate diagnosis of various cardiac defects, such as the ventricular septal defect, without cardiac catheterization.

In the present study we have investigated the potential of color flow mapping in obstetrics. 211 pregnant women were examined between the 15th and 40th weeks pulsed Doppler, but revealed no abnormalities in velocity waveform analysis.

The study is still in progress and only preliminary results have been illustrated, so it would be difficult to draw any final conclusions regarding the usefulness of flow mapping in obstetrics. Certain advantages are obvious. Fetal heart circulation can be accurately assessed during the second trimester. In cases of fetal cardiac structural defects it is possible to gain more information about disease and it provides for more accurate diagnosis, particularly by demonstration of abnormal intracardiac flow. The observation of flow profile presumes a new approach to blood flow analysis in peripheral vessels which potentially provides more data on normal and abnormal flow characteristics. It is our belief that the investigated technique may provide a promising new parameter and, along with additional clinical evidence, improve our understanding of fetal cardiovascular physiology and pathophysiology. In the meantime its real value should not be either underestimated or overestimated.

of pregnancy. 193 of them had normal pregnancies; 18 were abnormal, including 11 cases of insulin dependent diabetes, 2 cases of Rh-immunization, 2 cases of nonimmunologic fetal hydrops, 2 cases of fetal cardiac structural defects and 1 case of intrauterine growth retardation.

Intracardiac flow was clearly seen in $78 \%(35 / 45)$ of cases at the gestational age between the 20th and 24th weeks. After the 24th week the heart flow visualization rate gradually decreased to $31 \%(11 / 36)$ before term. In 2 cases of congenital heart abnormality flow mapping enabled clear visualization of reverse flow through the tricuspid valve and diagnosis of valvular insufficiency. The best results in studies of flow in peripheral vessels were obtained from umbilical vessels which were seen in all cases after the 15 th week. The flow visualization rate was much lower when the fetal aorta, intrahepatic umbilical vein and internal carotid artery were studied. The comparison between the diameter of the umbilical vein measured on the B-scan and flow width in the same vessel showed no significant difference $(t=0.26$; $\mathrm{p}<0.01 ; \mathrm{N}=209$ ). In optimum examination conditions two different flow components could be recognized in the umbilical vein. According to the specifications of the used equipment the central component represents 
fast unidirectional flow, while the peripheral component represents the high velocity gradient. The ratio of these two components is not constant during pregnancy and reflects flow profile changes. In two cases of severe Rhimmunization and in two cases of non-immune fetal hydrops significant flow profile changes could be observed as compared to the normal group. The finding was explained by marked vessel dilatation and lower blood viscosity in the cases.
The results suggest that color flow mapping can be useful in antenatal detection of congenital heart abnormalities because it affords visualization of intracardiac flow in a high proportion of cases if examination is performed during the second trimester. Flow profile analysis opens up new avenues in blood flow studies of fetal peripheral circulation but its usefulness should be confirmed by additional extensive in vitro and clinical studies.

Keywords: Color flow mapping, Doppler analysis, fetus, ultrasound.

\section{Zusammenfassung}

\section{Farb-Flowkodierung in der Geburtshilfe}

Studien über den Blutfluß sind inzwischen allgemein gebräuchlich zur Beurteilung der fetalen peripheren Zirkulation. Wenn man continuous wave oder gepulste Dopplergeräte benutzt; können die einfachen Doppleranzeigen, ausgelöst durch die intravasalen Blutbewegungen, auf unterschiedliche Arten beurteilt werden. Die spektralen Daten können zur Beurteilung der Blutgeschwindigkeit und des Blutvolumens, der Pulsqualitäten und von Turbulenzen genutzt werden. Alle diese Daten werden nur von einem eng umgrenzten Gebiet im Körper gewonnen, das Zielen ist entscheidend. Daten von einer bestimmten Körperregion zu gewinnen, erfordert somit sehr viel Können und Geduld. Farbflußkodierung, die kürzlich in die Klinik eingeführt wurde, bietet einen Überblick über Flußgeschwindigkeiten und -richtungen innerhalb eines Gebietes. Farbig kodierter Flow kann dargestellt werden, wenn am Ultraschalluntersuchungsgerät das Prinzip der Identifizierung von bewegenden Zielen benutzt wird (wie beim Radar). Schallwellen ersetzen in diesem Fall die Radiowellen.

Genutzt wird die Flußkodierung schon bei der Diagnose von angeborenen und erworbenen Krankheiten des Herzens bei Erwachsenen und Kindern. Sichtbarmachung des intrakardialen Flusses sorgt für eine schnelle und sichere Diagnose verschiedener Herzfehler, wie dem Ventrikel-Septum-Defekt, ohne Herzkatheterisierung.

In der vorliegenden Studie haben wir die Möglichkeiten der farbigen Flußkodierung in der Geburtshilfe erforscht. 211 schwangere Frauen wurden zwischen der 15. und 40. Schwangerschaftswoche untersucht. Davon hatten 193 eine normale Schwangerschaft; 18 Schwangerschaften verliefen anomal: 11 Fälle von insulinpflichtigen Diabetes, zwei Fälle von Rh-Immunisierung, zwei Fälle von nicht-immunologischem fetalen Hydrops, zwei Fälle von fetaler Herzanomalie, und ein Fall von intrauteriner Wachstumsretardierung.

Intrakardialer Fluß war bei $78 \%$ (35 von 45 ) im Gestationsalter zwischen 20 . und 24 . Woche deutlich zu sehen. Nach der 24. Woche nahm diese Rate allmählich bis zum Termin auf $31 \%$ (11 von 36 ) ab. In zwei Fällen kongenitaler Herzanomalie ermöglichte die Flußkodierung eine deutliche Darstellung des Gegenflusses durch die Trikuspidalklappe und die Diagnose einer Klappeninsuffizienz. Die besten Ergebnisse der Flow-Untersuchungen an peripheren Gefäßen wurden bei den Nabelgefäßen erzielt, die immer nach der 15 . Woche zu sehen waren. Die Rate der erfolgreichen Flowkodierung war viel geringer, wenn die fetale Aorta, die intrahepatische Nabelvene, oder die Carotis interna untersucht wurden. Der Vergleich zwischen dem mit dem B-Scan gemessenen Nabelvenendurchmesser und der Durchflußweite zeigten keine signifikanten Unterschiede $(\mathrm{t}=0,26 ; \mathrm{p}<0,01$; $\mathrm{N}=209$ ). Unter optimalen Untersuchungsbedingungen konnten in der Nabelvene zwei verschiedene Flußkomponenten unterschieden werden. Nach den Angaben des benutzten Gerätes handelt es sich bei der zentralen Komponente um den schnellen gerichteten Fluß, während die periphere Komponente den Hochgeschwindigkeitsgradienten darstellt. Die Relation zwischen den beiden Komponenten bleibt während der Schwangerschaft nicht konstant, sie spiegelt die Wechsel des Flußprofils wider. Verglichen zur normalen Gruppe konnten in zwei Fällen von schwerer Rh-Immunisierung und in zwei Fällen von nicht-immunologisch-bedingtem fetalen Hydrops erhebliche Veränderungen im Flußprofil beobachtet werden. Dieses Ergebnis wurde mit umschriebener Gefäß-Dilatation und niedrigerer Blutviskosität in diesen Fällen erklärt.

Die Ergebnisse zeigen, daß die farbliche Flußkodierung in der antepartalen Erfassung von angeborenen Herzfehlern nützlich sein kann, da sie, bei einer Untersuchung im zweiten Trimester, zu einem hohen Prozentsatz die intrakardialen Strömungsverhältnisse sichtbar macht. Flußprofiluntersuchungen eröffnen neue Wege für die Blutströmungsuntersuchungen an der fetalen peripheren Zirkulation, aber ihre Anwendbarkeit sollte erst noch durch ausgiebige Labor- und Klinikstudien überprüft werden.

Schlüsselwörter: Doppler Analyse, Farb-Flowkodierung, Fetus, Ultraschall. 


\section{Résumé}

\section{Doppler couleur en obstétrique}

Actuellement, on utilise de façon large l'étude des débits sanguins pour évaluer la circulation fœtale périphérique. A l'aide de matériel échographique couplé à doppler continu et à un doppler pulsé, on peut analyser de différentes manières les modifications de l'onde doppler brute provoquées par le déplacement sanguin à l'intérieur des vaisseaux. Pour estimer la vélocité sanguine et le volume dans le vaisseau, ainsi que les caractéristiques de la pulsatilité et la turbulence, on peut faire appel aux données spectrales. On obtient toutes ces données à partir de zones très limitées du corps, de telle sorte que l'orientation de la sonde est critique et des efforts longs et pénibles sont necessaires pour obtenir des données concernant la zone en question. La cartographie en couleur des flux, introduite recemment en pratique clinique, permet une vue d'ensemble des vélocités et des directions des flux au sein d'une zone donnée. Les flux codés en couleur peuvent être affichés en appliquant le principe de l'identification d'une cible mouvante (comme pour un radar) à un matériel de diagnostic ultrasonore au sein duquel on utilise des ondes sonores au lieu d'ondes radio.

On a déjà mis en évidence la valeur du doppler couleur pour le diagnostic des maladies cardiaques congénitales ou acquises chez l'adulte et chez l'enfant. La visualisation directe des flux intra-cardiaques permet de faire rapidement et de façon précise le diagnostic de nombreuses anomalies cardiaques, tel, par exemple, qu'un défaut ventriculaire septal, celà sans cathétérisme cardiaque.

Dans cette étude, nous avons exploré la valeur potentielle des cartographies en couleur des flux en obstétrique. 211 femmes enceintes ont été examinées entre la 15è et la 40è semaine de grossesse; 193 grossesses étaient normales; 18 étaient anormales, dont 11 avec diabète insulino-dépendant, 2 iso-immunisations rhésus, 2 hydrops fœetalis non immunologiques, 2 anomalies cardiaques fotales et 1 retard de croissance intra-utérin. Les flux intra-cardiaques ont été bien vus dans $78 \%$ des cas (35/45) entre la 20è et la 24è semaine d'âge gestationnel. Après la 24è semaine, le taux de visualisa-

Mots-clés: Doppler, doppler couleur, fœtus, ultrasons. tion des flux cardiaques diminue progressivement jusqu'à $31 \%(11 / 36)$ près du terme. En 2 cas d'anomalié cardique congénitale, la doppler couleur a permis une visualisation distincte des flux inverses par la valve tricuspidienne et le diagnostic de l'insuffisance valvulaire. On a obtenu les meilleurs résultats pour l'étude des flux au niveau des vaisseaux périphériques dans les vaisseaux ombilicaux qui ont été vus dans tous les cas après la 15 è semaine. Le pourcentage de visualisation des flux a été beaucoup plus faible lorsque l'on étudiait l'aorte fætale, la veine ombilicale intra-hépatique et l'artère carotide interne.

La comparaison entre le diamètre de la veine ombilicale mesuré en échographie B et l'épaisseur du flux au niveau du même vaisseau ne montre pas une différence significative $(t=0,26 ; p<0,01 ; N=209)$. On peut reconnaître deux composantes différentes du flux au niveau de la veine ombilicale dans des conditions optimales d'examen. Selon la spécificité du matériel utilisé, la composante centrale représente le flux rapide unidirectionel, tandis que la composante périphérique représente le gradient de haute vélocité.

Le rapport de ces deux composantes n'est pas constant au cours de la grossesse et il reflète les modifications des profils du flux. En comparaison du groupe normal, on a pu observer des modifications significatives des profils du flux dans deux cas d'iso-immunisations rhésus et dans deux cas d'hydrops fœtalis non-immunologiques. On a expliqué ces données par la dilatation importante des vaisseaux et par la viscosité sanguine diminuée dans ces cas.

Les résultats suggèrent que le doppler couleur peut être utile pour le dépistage prénatal des cardiopathies congénitales car il permet la visualisation des flux intra-cardiaques dans une proportion élevée de cas si l'examen est réalisé au cours du second trimestre. L'analyse des profils de flux ouvre une nouvelle voie dans l'étude des flux sanguins de la circulation fœtale périphérique, toutefois il faut, pour confirmer son utilité, que des études supplémentaires in-vitro et en clinique, soient effectuées.

\section{References}

[1] Eik-Nes SH, HC BRubaKk, MK UsteIN: Measurement of human fetal blood flow. Br Med J 1 (1980) 284

[2] Fitzgerald DE, JE Drumm: Non-invasive measurement of human fetal circulation using ultrasound: a new method. Br Med J 2 (1977) 1450

[3] Griffin D, T COHEN-Overbeek, S CAMpbell: Fetal and uteroplacental blood flow. Clin Obstet Gynaecol 10 (1983) 565
[4] Kasai C, K NameKawa: Real-time two-dimensional blood flow imaging using ultrasound Doppler. In: KuRJAK A, G Kossoff (eds): Recent advances in ultrasound diagnosis 5. Excerpta Medica, Amsterdam 1986

[5] KurJak A, B RajhVAJN: Ultrasonic measurements of umbilical blood flow in normal and complicated pregnancies. J Perinat Med 10 (1982) 3 
[6] Kyo S: Congenital heart malformations diagnosed by color flow mapping. In: KURJAK A, G KossofF (eds): Recent advances in ultrasound diagnosis 6 . Excerpta Medica, Amsterdam (in press)

[7] Soma H: Single umbilical artery with congenital malformations. In: GRUNDMANN E (ed): Current topics in pathology. Springer Verlag, Berlin 1979

[8] TRUdinger BJ, WB Giles, CM CoOK: Flow velocity waveforms in the maternal uteroplacental and fetal umbilical placental circulations. Am J Obstet Gynecol 151 (1985) 155

[9] Wells PNT: Biochemical ultrasonics. Academic Press, London 1977
[10] WladimirofF JW, J McGhIE: Ultrasonic assessment of fetal cardiovascular geometry and function in human fetus. Br J Obstet Gynaecol 88 (1981) 1241

Received October 28, 1986. Accepted December 19, 1986.

Asim Kurjak, M. D., Ph. D.

Professor

Ultrasonic Institute

Medical Faculty, University of Zagreb

P. Miškine 64

41000 Zagreb, Yugoslavia 